\title{
PREDICTORS OF UndER-REPORTING OF UnPROTECTED SEX WITH CLIENTS AS Measured by Semen Detection among Female Sex Workers under HIV Treatment as PREVEntION OR PRE-EXPOSURE PROPHYLAXIS IN BENIN
}

\author{
Giguère K, ${ }^{1,2}$ Béhanzin L, ${ }^{1,3,4}$ Guédou FA, ${ }^{1,3,4}$ Goma-Matsétsé E, ${ }^{3}$ Leblond FA, ${ }^{5}$ Zannou DM, ${ }^{6,7}$ Alary $M^{1,2,8}$
}

${ }^{1}$ Centre de recherche du CHU de Québec - Université Laval, Québec, Canada; ${ }^{2}$ Département de médecine sociale et préventive Université Laval, Québec, Canada; ${ }^{3}$ Dispensaire IST, Cotonou, Bénin; ${ }^{4}$ École Nationale de Formation des Techniciens Supérieurs en Santé Publique et en Surveillance Épidémiologique - Université de Parakou, Parakou, Bénin; ${ }^{5}$ Consultant indépendant, Montréal, Canada; ${ }^{6}$ Faculté des sciences de la santé - Université d'Abomey-Calavi, Cotonou, Bénin; ${ }^{7}$ Centre national hospitalier universitaire HMK, Cotonou, Bénin; 8Institut national de santé publique du Québec, Québec, Canada

\section{Background}

* Treatment as prevention (TasP) and pre-exposure prophylaxis (PrEP) may result in condom migration and therefore require careful monitoring of unprotected sex.

* Self-report of unprotected sex is subject to biases.

* Under-reporting has been previously observed through vaginal detection or prostate-specific antigen (PSA), a biomarker of recent semen exposure (2 days), among female sex workers (FSW) reporting no unprotected sex.

* However, little is known about the factors leading to underreporting of unprotected sex among FSW.

* The objective of this study was to assess predictors of underreporting of unprotected sex among FSW at baseline of a TasP/PrEP demonstration study.

\section{Results}

\section{Methods}

* Unprotected sex in the previous 2 days was assessed by face-toface interview and vaginal detection of PSA at baseline of a TasP/ PrEP prospective demonstration project (2014-2016)

* Under-reporting : not reporting any unprotected sex but testing positive for PSA.

* Socio-demographic, behavioural, and biological variables were tested for their association with under-reporting using bivariate Poisson regression models.

* Variables significantly associated $(p<0.05)$ with under-reporting were included in a multivariate Poisson regression model.

* Among the 361 FSW participating in the study, we excluded those reporting a regular sexual partner in the last 2 days because self-reported condom use was uncommon with such partners. This resulted in a final sample size of 274 for the present analysis.

\section{Table 1 - Baseline characteristics $(n=274)$}

$\begin{array}{lrl}\text { Age, mean (sd) (years) } & 34 & (9) \\ \text { Beninese }^{a} & 140 & (51.1) \\ \text { Christian }^{\text {b }} & 204 & (74.7) \\ \text { Marital status } & & \\ \quad \text { Married } & 2 & (0.7) \\ \quad \text { Divorced/separated } & 118 & (43.2) \\ \quad \text { Widowed } & 57 & (20.9) \\ \quad \text { Single } & 96 & (35.2) \\ \text { Had a regular partner in the last } & 153 & (55.8) \\ \quad 12 \text { months } & & \\ \text { Education } & & \\ \quad \text { None } & 89 & (32.7) \\ \quad \text { Primary } & 100 & (36.8) \\ \quad \text { Secondary } & 75 & (27.5) \\ \quad \text { University } & 8 & (2.9) \\ \text { Alcohol use } & 174 & (63.5) \\ \text { Nb of clients in the last 2 days, } & 4.3 & (4.6) \\ \quad \text { mean (sd) } & & \\ \text { HIV positive } & 86 & (31.4) \\ \text { PSA positive } & 75 & (27.4) \\ \text { Under-reported unprotected sex } & 65 & (23.7)\end{array}$

a Other nationalities: Togolese, Ghanaian, Nigerian, Nigerien, Cameroonian

b Other religions: Muslim, Traditional religion and no religion

\section{Disclosure of interest}

Funding: Bill \& Mellinda Gates Foundation (OPP1098973) and Canadian Institutes of Health Research (ROH-115205 and FDN143218). The views expressed herein are those of the authors and do not necessarily reflect the official policy or position of the Bill \& Melinda Gates Foundation.
TABLE 2 - BIVARIATE AND MULTIVARIATE ANALYSES OF THE DETERMINANTS ASSOCIATED TO UNDER-REPORTING OF UNPROTECTED SEX IN THE LAST 2 DAYS

\begin{tabular}{|c|c|c|c|c|}
\hline Variable & $\mathrm{n}$ & $\begin{array}{c}\text { Under- } \\
\text { reporting } \\
(\%)\end{array}$ & $\begin{array}{c}\text { Bivariate } \\
\text { PR }(95 \% \mathrm{Cl})\end{array}$ & $\begin{array}{l}\text { Multivariate a } \\
\text { PR }(95 \% \mathrm{Cl})\end{array}$ \\
\hline \multicolumn{5}{|l|}{ Religion } \\
\hline Christian & $41 / 204$ & 20.1 & $0.58(0.38-0.88)$ & $0.58(0.38-0.88)$ \\
\hline Other ${ }^{b}$ & $24 / 69$ & 34.8 & Ref. & Ref. \\
\hline \multicolumn{5}{|l|}{ Education } \\
\hline None & $28 / 89$ & 31.5 & Ref. & Ref. \\
\hline Any & $36 / 183$ & 19.7 & $0.63(0.41-0.96)$ & $0.67 \quad(0.44-1.02)$ \\
\hline \multicolumn{5}{|l|}{ Alcohol use } \\
\hline No & $31 / 100$ & 31.0 & Ref. & Ref. \\
\hline Yes & $34 / 174$ & 19.5 & $0.63(0.41-0.96)$ & $0.60 \quad(0.40-0.91)$ \\
\hline \multicolumn{5}{|c|}{$\begin{array}{l}\text { Had a regular partner } \\
\text { in the last } 12 \text { months }\end{array}$} \\
\hline No & $37 / 121$ & 30.6 & Ref. & Ref. \\
\hline Yes & $28 / 153$ & 18.3 & $0.60 \quad(0.39-0.92)$ & $0.65(0.42-0.99)$ \\
\hline
\end{tabular}

PR: proportion ratio

a Multivariate analysis : including religion, education, alcohol use and having had a regular partner in the last 12 months

b Including Muslim, Traditional religion and no religion

\section{Conclusion}

* Our results suggest that being Christian, alcohol use, and having had a regular partner in the last year were negatively associated with under-reporting of unprotected sex with clients among FSW from Benin.

* Awareness of the predictors of underreporting of unprotected sex might improve our capacity to better target FSW having unprotected sex with effective prevention approaches. 